\title{
Studi Tentang Kepuasan Wisatawan Dampak Dari Pengembangan Wisata Di Bali Ndeso Kampung Flory Sebagai Wisata Alam Dan Kulineri
}

\author{
Wisnu Hadi \\ Universitas Bina Sarana Informatika \\ E-mail : wisnu.wsh@bsi.ac.id
}

\begin{abstract}
Tourism always has an impact on the economic and social aspects of the residents around the tourist attractions, therefore development and management are always a serious concern for tourism managers. In this study discussed the study of tourist satisfaction as a result of tourism development in Bali Ndeso, Flory Village. Using descriptive qualitative research, researchers want to disclose aspects of service, facilities, prices and satisfaction offered to visitors. The rating of tourists towards the management of tourism objects as a tourist development in Bali Ndeso in this study the majority gave good ratings. Indicators of reliable and responsive services have been considered good. Then the belief and empaty indicators are also considered good. The aspect of facilities in consideration and land planning is also well appreciated by tourists. The price factor offered is also assessed in accordance with the quality of the products in Bali Ndeso and the prices that are considered to be quite competitive with competitors of similar tourism objects elsewhere. The location of tourism objects is also considered good because of its strategic location and easy access. The researcher found that tourist satisfaction was judged to be good because of the success in complaining the complaints of tourists and completing the work well such as being able to know the desires and diagonalize the problem quickly.
\end{abstract}

\section{Keywords: Development, Satisfaction and Travelers}

Abstrak - Pariwisata selalu memberikan dampak terhadap ekonomi dan sosial warga sekitar obyek wisata untuk itu pengembangan dan pengelolaan selalu menjadi perhatian serius bagi pengelola wisata. Dalam penelitian ini membahas studi tentang kepuasaan wisatawan sebagai dampak dari pengembangan wisata di Bali Ndeso Kampung Flory. Menggunakan penelitian yang bersifat deskriptif kualitatif, peneliti ingin mengungkapkan tentang aspek-aspek pelayanan, fasilitas, harga dan kepuasaan yang ditawarkan kepada wisatawan. Penilaiaan wisatawan terhadap pengelolaan obyek wisata sebagai pengembangan wisata di Bali Ndeso dalam penelitian ini mayoritas memberikan penilaian yang baik. Indikator pelayanan yang handal dan tanggap sudah dinilai baik. Kemudian indikator keyakinan dan empaty juga dinilai baik. Aspek fasilitas dalam pertimbangan dan perencanaan lahan juga diapresiasi dengan baik oleh wisatawan. Faktor harga yang ditawarkan juga dinilai sesuai dengan kualitas produk yang ada di Bali Ndeso serta harga yang dinilai cukup bersaing dengan kompetitor obyek wisata yang sejenis ditempat lain. Aspek lokasi obyek wisata juga dinilai baik karena lokasi yang strategis dan mudah diakses. Peneliti menemukan bahwa kepuasaan wisatawan sudah dinilai baik karena keberhasilan dalam menengani keluhan wisatwan dan menyelesaikan pekerjaan dengan baik seperti mampu mengetahui keinginan dan mendiagonis permasalahan dengan cepat.

Kata Kunci : Pengembangan, Kepuasaandan Wisatawan

\subsection{Latar Belakang}

(BPS) mengatakan jumlah kunjungan wisatawan luar negeri atau wisman yang berkunjung ke Indonesia selama tahun 2018 sebesar 15,81 juta orang. Jumlah tersebut tidak sesuai target yang diingin dicapai pemerintah yaitu sebesar 17 juta orang. Target yang tidak dicapai tentunya dianalisis ada penyebabnya misalnya promosi, infrastruktur serta banyak spot wisata atau distinasi wisata yang menarik dan berbeda dengan destinasi yang lain. Pariwisata adalah salah satu sumber pertumbuhan ekonomi negara kita dimasa depan selain minyak dan gas yang mulai tipis cadangannya serta pajak-pajak. Untuk itu pembangunan pariwisata perlu dibangun secara serius oleh pemerintah pusat dan daerah secara bersama-sama.

Pemerintah selama ini sudah membangun berbagai sarana-prasarana untuk menunjang pertumbuhan ekonomi salah satunya dengan membangun jalan Tol dari Merak sampai Surabaya. Pembangunan jalan Tol tersebut akan mempengaruhi pertumbuhan ekonomi daerah yang dilewati jalan Tol tersebut terutama ekonomi wisata daerah sehingga akses menuju obyek distinasi wisata dapat cepat dan mudah dikunjungi wisatawan. Pemerintah pusat dalam hal ini Kementerian 
Pariwisata selalu mengatakan bahwa wisatawan khususnya wisatawan asing selalu tertarik dengan destinasi wisata yang menarik dan berbeda dengan yang lain terutama wisata alam , wisata budaya dan wisata minat khusus. Daerah Istimewa Yogyakarta mempunyai spot-spot wisata yang menarik dan sekarang mulai banyak terkenal wisatawan khususnya wisatawan nusantara. Peran media massa dan sosial menjadikan spot-spot wisata banyak dikunjungi beribu-ibu wisatawan terutama saat hari libur.

Salah satu destinasi wisata yang banyak dikunjungi wisatawan di Daerah Istimewa Yogyakarta adalah obyek wisata Bali Ndeso Kampung Flory yang ada di Kabupaten Sleman, spot wisata yang bersifat wisata alam, pendidikan dan kuliner yang beberapa tahun ini terkenal dan salah satu menjadi tujuan para wisatawan saat berkunjung di Yogyakarta. Pengembangan wisata Bali Ndeso Kampung Flory dari rintisan warga dan pemuda desa dari proses yang pelan-pelan dibangun dari kecil sekarang menjadi besar. Obyek wisata ini menjadi contoh pelaku wisata daerah lain yang ingin mengembangkan wisata daerahnya sehingga nantinya menjadi terkenal dan besar seperti Kampung Flory ini. Kegiatan studi wisata dan studi banding menjadikan Bali Ndeso Kampung Flory menjadi wisata pendidikan bagi yang akan mengembangkan wisata sejenis. Segala sarana-prasarana di obyek wisata ini sangatlah lengkap dan jarak serta akses ke Bali Ndeso kampung wisata Flory sangatlah mendukung obyek wisata banyak ramai dikunjungi setiap hari dan hari libur.

Aspek-aspek kepuasaan dari hasil pengembangan pariwisata Bali Ndeso kampung Flory di kabupaten Sleman menjadikan penelitian untuk dikaji dan diteliti tentang kepuasaan wisatwan dari hasil pengembangan obyek wisata tersebut. Tentu saja hal ini dikaitkan dengan pelayanan dan pemasaran pariwisata yang dilakukan oleh pelaku-pelaku wisata di obyek tersebut. Unsurunsur yang menjadikan wisatawan betah dan berlama-lama diobyek wisata Bali Ndeso menarik untuk dikaji dan persepsi wisatawan selama ini menilai pengelolaan sudah ditangani dengan baik atau belum.

\subsection{Kajian Pustaka}

\subsubsection{Pengertian Pariwisata}

Istilah pariwisata yang termaktup di Undang-Undang No.10 Tahun 2009 tentang Kepariwisataan, pada Bab I pasal I mengenai ketentuan umum dan isi pasal tersebut dapat disimpulkan bahwa wisata adalah kegiatan perjalanan yang dilakukan oleh seseorang atau sekelompok orang dengan mengunjungi tempat tertentu untuk tujuan rekreasi, pengembangan pribadi, atau mempelajari keunikan daya tarik wisata yang dikunjungi dalam jangka waktu sementara.

Sedangkan pengertian Pariwisata dari seorang Suwantoro (2002 : 27), pariwisata diartikan sebagai bentuk. suatu proses kepergian sementara dari seorang, lebih menuju ketempat lain diluar tempat tinggalnya. Pengertian lain dari Pariwisata adalah berbagai macam kegiatan wisata dan didukung berbagai fasilitas serta layanan yang disediakan oleh masyarakat, pengusaha, pemerintah, dan Pemerintah Daerah.

\subsubsection{Pengertian Wisatawan}

Wisatawan merupakan unsur utama dalam pariwisata karena terjadinya kegiatan pariwisata tergantung pada adanya interaksi antara wisatawan dan objek wisata, yang didukung dengan berbagai sarana prasarana pariwisata. Menurut Kuntowijoyo, (2006:55) bahwa sebuah objek wisata akan dikatakan menarik jika banyak di kunjungi wisatawan.

Wisatawan ia adalah aktor dalam kegiatan wisata. Berwisata menjadi sebuah pengalaman manusia untuk menikmati, mengantisipasi dan mengingatkan masa masa di dalam kedalam kehidupan (Ismayanti, 2010:2).

Sedangkan Sihite (2000:49) pengertian wisatawan dapat digolongkan menjadi dua, yaitu:

1. Wisatawan nusantara adalah wisatawan dalam negeri atau wisatawan domestik atau asli dari penduduk negara tersebut.

2. Wisatawan mancanegara adalah warga negara suatu negara yang mengadakan perjalanan wisata keluar lingkungan dari negaranya (memasuki negara lain).

\subsubsection{Obyek Wisata dan Daya Tarik Wisata}

Istilah objek dan daya tarik wisata

menurut Undang-undang Nomor 9

Tahun 1990 yaitu yang menjadi sasaran perjalanan wisata yang meliputi :

1. Ciptaan Tuhan Yang Maha Esa, yang berwujud keadaan alam serta floradan fauna, seperti : pemandangan alam, panorama indah, hutan rimba dengan tumbuhan hutan tropis, serta binatangbinatang langka.

2. Karya manusia yang berwujud museum, peninggalan purbakala, peninggalan sejarah, seni budaya, wisata agro (pertanian), wisata tirta (air), wisata petualangan, taman rekreasi, dan tempat hiburan. 
3. Sasaran wisata minat khusus, seperti : berburu, mendaki gunung, gua, industri dan kerajinan, tempat perbelanjaan, sungai air deras, tempat- tempat ibadah, tempat-tempat ziarah dan lain-lain

\subsubsection{Pelayanan Pariwisata}

Pelayanan diartikan dalam UndangUndang Nomer 8 Tahun 1999 tentang Perlindungan konsumen adalah setiap layanan yang berbentuk pekerjaan atau prestasi yang disediakan bagi masyarakat untuk dimanfaatkan oleh konsumen.

Kemudian pendapat Abdul Majid (2009

:35) bahwa pelayanan dapat diartikan sebagai berikut :

1. Sebuah kata kerja yang bersifat aktif bukan pasif, dinamis bukan statis, proaktif bukan reaktif, tanggap dan peduli terhadap orang lain bukan cuek, mau menolong orang lain bukan diam atau menghindar.

2. Suatu tindakan nyata dan segera untuk menolong orang lain (pelanggan, mitra kerja, mitra bisnis dan sebagainya) disertai senyuman yang ramah dan tulus.

\subsubsection{Pemasaran Pariwisata}

Pengembangan pariwisata bagi destinasi wisata tidak lepas dari kegiatan pemasaran pariwisata karena kegiatan tersebut yang menyebabkan orang akan berkunjung ke obyek wisata yang dimilikinya. Pemasaran pariwisata tentu ada produk yang ditawarkan ke wisatawan sehingga orang akan mengeluarkan uangnya untuk menikmati produk tersebut. Pemasaran adalah suatu proses sosial dan managerial yang didalamnya individu dan kelompok mendapatkan apa yang mereka butuhkan dan inginkan dengan menciptakan, menawarkan dan secara bebas mempertukarkan produk yang bernilai dengan pihak lain(Kotler, 2002:9).

Produk wisata sebagai salah satu obyek penawaran dalam pemasaran pariwisata memiliki unsur-unsur utama yang terdiri 3 bagian (Oka A. Yoeti, 1996:211) :

1. Daya tarik daerah tujuan wisata, termasuk didalamnya citra yang dibayangkan oleh wisatawan

2. Fasilitas yang dimiliki daerah tujuan wisata, meliputi akomodasi, usaha pengolahan makanan, parkir, trasportasi, rekreasi dan lain-lain.

3. Kemudahan untuk mencapai daerah tujuan wisata tersebut.

\subsubsection{Kepuasaan Wisatawan}

Dalam pengelolaan obyek wisata satu dengan yang lain bahwa persaingan obyek wisata atau desnitasi wisata akan semakin ketat untuk itu faktor kepuasan pengunjung atau wisatawan menjadi perhatian yang serius. Kegiatan pelayanan dan kepuasan pengunjung merupakan aspek penting dalam rangka menarik pengunjung untuk datang kembali ke obyek wisata tersebut. Menurut Nasution yang dikutip Abdul Majid (2009:168) bahwa kepuasaan pelanggan dapat didefinisikan secara sederhana yaitu suatu keadaan yang dapat memenuhi kebutuhan, keinginan, dan harapan pelanggan melalui produk yang dikonsumsi.

\subsection{Metode Penelitian}

Untuk menghasilkan peneltian yang sesuai dengan tujuan penelitian maka dalam jenis penelitian yang dilakukan penulis menggunakan jenis penelitian yang bersifat Deskriptif Kualitatif. Jenis penelitian deskriptif kualitatif adalah penelitian yang menghasilkan data deskriptif dengan mengumpulkan data berupa kata-kata baik tertulis maupun lisan dari orang-orang dan perilaku yang diamati. Nantinya penelitian deskriptif kualitatif ini cenderung tidak mencari atau menerangkan saling hubungan dan menguji hipotesis, meski tidak menutup kemungkinan adanya dalam bentuk angka-angka.

Penelitian deskriptif kualitatif menurut Sugiyono (2008:35) diartikan sebagai metode yang digunakan untuk menggambarkan atau menganalisis suatu hasil penelitian tetapi tidak digunakan untuk membuat kesimpulan yang lebih luas. Penelitian dekriptif kualitatif akan dilakukan di obyek wisata Bali Ndeso Kampung Flory, Desa Tridadi, Kecamatan Sleman, Kabupaten Sleman. Penelitian akan dilakukan oleh peneliti selama 2 minggu di bulan Februari 2019 dan peneliti akan terjun langsung ke obyek wisata Bali Ndeso Kampung Flory, Desa Tridadi, Kecamatan Sleman, Kabupaten Sleman.

Untuk mendapatkan data yang sesuai dengan kenyataan maka penelitian ini mengunakan instrumen sebagai berikut:

1. Wawancara langsung

Metode wawancara adalah proses tanya jawab dalam penelitian yang berlangsung secara lisan kepada pengelola, pengurus dan juga sejumlah wisatawan atau pengunjung yang berkunjung di obyek wisata tersebut.

2. Kuesioner

Kuesioner merupakan alat pengumpulan data dengan membuat daftar pertanyaan yang diisi oleh wisatawan atau penggunjung yang berkunjung atau sudah berkunjung di wisata Bali Ndeso Kampung Flory Desa Tridadi, Kecamatan Sleman, Kabupaten Sleman, DIY

3. Pengamatan langsung (direct obsevation) Metode Observasi yaitu cara memperoleh data yang dilakukan dengan cara 
mengamati dan mencatat secara sistematisk gejala- gejala yang diselidiki. Dengan meninjau kegiatan-kegiatan dan kondisi yang ada di wisata Bali Ndeso Kampung Flory Kecamatan Sleman, Kabupaten Sleman, DIY tersebut supaya penulis dapat melihat dengan jelas bagaimana keadaannya.

4. Dokumentasi

Dokumentasi ini dilakukan guna mendapatkan foto atau gambar kegiatan wisata Bali Ndeso Kampung Flory Kecamatan Sleman, Kabupaten Sleman, DIY.

5. Studi Pustaka

Studi Pustaka dilakukan untuk mencari dan mendapatkan data-data yang bersifat teoritis dan berhubungan dengan penelitian yang sedang dilakukan pengumpulan data kepustakaan dilakukan terhadap data dan informasi dalam bentuk buku, laporan hasil penelitian dan sumber lainnya.

Analisis data yang digunakan dalam penelitian ini adalah analisis deskriptif, kualitatif yang pengujiannya bertitik tolak dari data yang telah terkumpul kemudian dilakukan penarikan kesimpulan. Disini peneliti analisa data dengan metode statistik deskriptif yang berbentuk tabel-tabel frekuensi. Data kualitatif dan kuantitatif yang terkumpul ditabulasi, diklasifikasi, diolah dan dianalisis kemudian diinterpretasikan untuk menentukan kesimpulan dan rekomendasi kepada pengelola wisata Bali Ndeso Kampung Flory Kecamatan Sleman, Kabupaten Sleman, DIY agar wisata air dapat berkembang dan maju sebagai destinasi wisata alternatif di wilayah Yogyakarta.

\subsection{Hasil Dan Pembahasan}

Obyek wisata Bali Ndeso merupakan bagian dari kampung Wisata Kampung Flory di Desa Tridadi, Kecamatan Sleman, Kabupaten Sleman di Propinsi Daerah Istimewa Yogyakarta berada di lahan seluas empat hektar yang menempati tanah pribadi dan tanah desa. Obyek wisata ini pada mulanya dikembangkan sebagai tempat budidaya tanaman hias dan tanaman buah. Selanjutnya oleh pengelola agar menarik wisatawan dikembangkan menjadi wisata minat khusus sehingga wisatawan dapat belajar tentang tanaman hias, perkebunan dan pertanian.

Kampung Wisata Kampung Flory ini dapat dipetakan menjadi beberapa zona, antara lain :

1. Zona pertama yang terdiri area pertanian dengan sebutan zona Taruna Tani. Untuk luas area ini ada 1 hektare yang didalamnya terdapat usaha tanaman hias, tanaman buah, dan kuliner.

2. Zona kedua disebut zona Desa Wisata atau disebut Dewi Flory yang mempunyai luas area 1 hektare merupakan kawasan desa wisata yang menyajikan jasa penginapan (homestay), outbond, dan pelatihan kewirausahaan agrobisnis.

3. Zona ketiga disebut zona Agro Bush, lahan seluas 2 hektare yang menyajikan wisata petik buah langsung, wisata edukasi, dan pelestarian lingkungan.

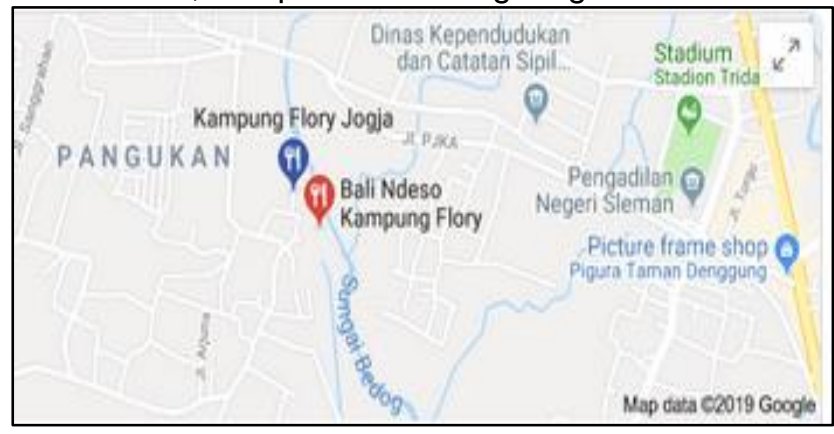

Gambar 1. Lokasi Wisata Kampung Flory

Lokasi wisata Bali Ndeso kampung Flory yang sangat strategis mempengaruhi banyak pengunjung untuk berwisata dengan jenis wisata pendidikan, kuliner atau wisata alam untuk mencari ketenangan dan kenyaman. Lokasi ini sangat lengkap untuk belajar dengan alam karena di sini wisatawan dapat belajar dengan alam seperti bertani, berkebung dan berternak.

Wisata Bali Ndeso Kampung Flory mempunyai beberapa arena ketangkasan yang telah dibangun dan siap dipergunakan untuk kegiatan outbound. Setiap hari banyak sekolah dari Pendidikan Usia Dini, Taman Kanak-Kanak sampai Sekolah Dasar menggunakan arena outbound di area wisata ini sebagai wisata pendidikan. Banyak kolamkolam dan selokan air yang digunakan anakanak sampai remaja dan orang tua untuk bermain air seperti mandi, terapi ikan atau berrendam sehingga menjadikan obyek wisata ini disebut dengan Bali Ndeso karena wisatawan diajak kembali kea lam pedesaan yang asri dan tenang.

Obyek wisata kurang lengkap tanpa wisata kulineri untuk itu pengunjung wisata Bali Ndeso Kampung Flory Sleman juga dapat menikmati sajian makanan dan minuman yang ditawarkan oleh resto atau rumah makan yang berciri khas pedesaan berada di kawasan wisata tersebut. Untuk menikmati sajian makanan dan minuman disediakan meja kursi di bangunan joglo utama dan lesehan di bangunan kecil dengan desain kandang ternak sapi sehingga kita seperti kembali di alam pedesaan yang penuh kesederhanaan. 
Berbagai macam menu makanan dan minuman yang ditawarkan menu pedesaan sehingga menarik pengunjung yang ingin menikmati. Harga yang ditawarkan terbilang standar untuk harga makanan disebuah restoran di kawasan wisata. Secara keseluruhan Kampung Flory dapat menjadi alternatif pilihan berwisata bersama keluarga sambil melihat tanaman hias atau sebagai tempat melaksanakan kegiatan outbound.

Pengelola wisata alam Bali Ndeso Kampung Flory Sleman menerapkan pengelolaan obyek wisata ini dengan basis pemberdayaan masyarakat dimana masyarakat disekitar obyek wisata tersebut dilibatkan dalam tenaga kerja atau bekerja. Sebanyak 30 orang tenaga kerja untuk warung kulineri di ambil dari masyarakat di sekitar wisata Bali Ndeso Kampung Flory Sleman. Kemudian tenaga untuk pengelolaan outbound juga melibatkan pemuda-pemuda dari wisata Bali Ndeso Kampung Flory Sleman. Sehingga obyek wisata ini dapat meningkatkan ekonomi penduduk setempat dan menciptakan lapangan pekerjaan.

Untuk pemberdayaan masyarakat yang lain, wisata kulineri di wisata Bali Ndeso Kampung Flory Sleman melibatkan masyarakat sebagai supplier atau pemasok kebutuhan restaurant wisata Bali Ndeso Kampung Flory Sleman seperti ikan tawar, ayam, sembako, sayur-mayur dan kebutuhan bahan yang lain. Masyarakat menyadari bahwa wisata Bali Ndeso Kampung Flory Sleman akan selalu menjadi daya tarik wisatawan untuk berkunjung sehingga mereka ikut bertanggungjawab bersama pengelola untuk melayani dengan baik dan professional.

Kepuasaan wisatawan sangat berarti bagi pengelola dan masyarakat di wisata Bali Ndeso Kampung Flory Sleman untuk itu dengan pelayanan yang baik dan professional mereka terus-menerus dilakukan. Hasil pengelolaan dan pemberdayaan masyarakat dalam mengurus wisata Bali Ndeso Kampung Flory Sleman dimata wisatawan menjadi penilaaian tentang kepuasaan wisatawan menggunakan produk dan jasa wisata di obyek tersebut.

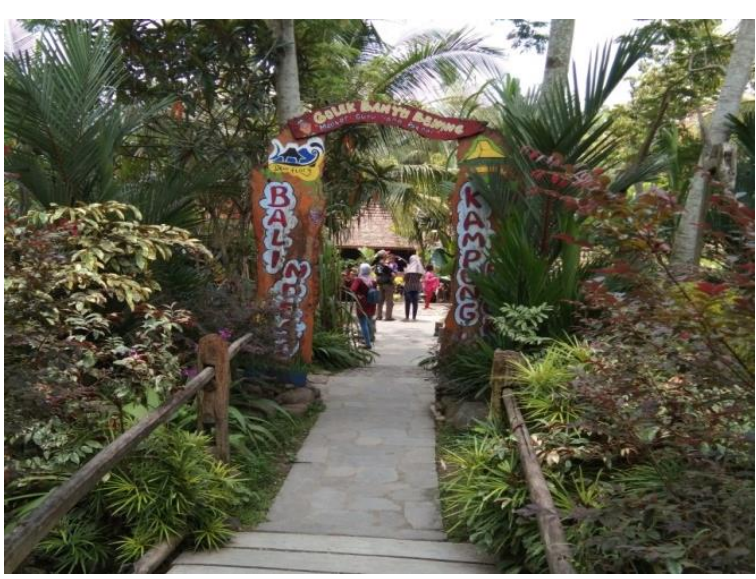

Gambar 2. Suasana Wisata Bali Ndeso Kampung Flory

\subsubsection{Data Identitas Pengunjung Wisata} Bali Ndeso Kampung Flory Sleman

Penelitian ini untuk mengetahui kepuasaan pengunjung terhadapa pengelolaan dan pemberdayaan masyarakat kepada wisatawan di wisata Bali Ndeso Kampung Flory Sleman. Aspek-aspek pelayanan, fasilitas, harga, lokasi wisata, serta kepuasaan pengunjung menjadi indikator tentang pengelolaan wisata Bali Ndeso Kampung Flory Sleman sudah berjalan dengan baik atau belum. Hanya dengan 25 sampel sebagai obyek penelitian ini mereka memberi penilain tentang aspek-aspek diatas nantinya menjadi indikator pengelolaan obyek wisata tersebut dapat memberi kepuasaan atau tidak.

Tabel 1. Data Karakteristik Wisatawan Bali Ndeso Kampung Flory

\begin{tabular}{|c|c|c|c|}
\hline Keterangan & Keterangan & Frekuensi & Persentase \\
\hline \multirow{3}{*}{$\begin{array}{l}\text { Jenis } \\
\text { Kelamin }\end{array}$} & Perempuan & 5 & $20 \%$ \\
\hline & Laki-Laki & 20 & $80 \%$ \\
\hline & Total & 20 & $100 \%$ \\
\hline \multirow[t]{5}{*}{ Usia } & 15-24 tahun & 5 & $20 \%$ \\
\hline & 25-34 tahun & 4 & $16 \%$ \\
\hline & 35-45 tahun & 13 & $52 \%$ \\
\hline & $>46$ tahun & 3 & $12 \%$ \\
\hline & Total & 25 & $100 \%$ \\
\hline
\end{tabular}
kepuasaan wisatawan yang berkunjung ke obyek wisata Bali Ndeso Kampung Flory, Kabupaten Sleman bahwa wisatawan yang saya teliti $80 \%$ berjenis kelamin laki-laki dengan usia yang paling dominan umur 35-45 tahun sebanyak $52 \%$.Obyek wisata ini banyak dikunjungi wisatawan orang tua karena wisatanya yang alami dan banyak kulineri yang disajikan menu desa atau tradisional sehingga sangat disukai para orang tua.

Pada saat hari biasa obyek wisata ini sering dikunjungi wisatawan khususnya orang tua untuk melakukan senam sehat orang tua. Minat wisata ini dimana-mana banyak disukai oleh orang tua karena sambil olah raga juga berwisata. Setiap waktu obyek wisata ini 
banyak dibooking khususnya pendopo atau gazebo untuk acara reuni orang tua dimana tempatnya yang mendukung dan mudah dijangkau dari mana saja serta akses jalan yang mudah dan baik.

Tabel 2. Data Asal Daerah Pengunjung Bali Ndeso Kampung Flory

\begin{tabular}{|c|l|c|c|}
\hline No. & \multicolumn{1}{|c|}{ Keterangan } & Frek & Persentase \\
\hline 1. & Kabupaten Sleman & 11 & $44 \%$ \\
\hline 2. & Kabupaten Bantul & 6 & $24 \%$ \\
\hline 3. & Kabupaten Kulon Progo & 2 & $8 \%$ \\
\hline 4. & Kabupaten Gunung Kidul & 0 & $0 \%$ \\
\hline 5. & Kota Yogyakarta & 3 & $12 \%$ \\
\hline 6. & Luar Propinsi DIY & 3 & $8 \%$ \\
\hline & Total & 25 & $100 \%$ \\
\hline
\end{tabular}

Pada penelitian ini pengunjung dari kabupaten Sleman masih mendominasi sebanyak 44\% karena lokasi berada di wilayah Kabupaten Sleman. Kemudian diikuti dari wisatawan dari Kabupaten Bantul sebanyak 24\%. Sedangkan dari Kota Yogyakarta dan kabupaten Kulon Progo sebanyak $12 \%$ dan $8 \%$. Saat penelitian dari luar Propinsi Yogyakarta ada $8 \%$ yaitu dari kabupaten Magelang dan Cilacap, Jawa Tengah.

Tabel 3. Data Tingkat Pendidikan Wisatawan Bali Ndeso Kampung Flory

\begin{tabular}{|c|l|c|c|}
\hline No. & Keterangan & Frekuensi & Persentase \\
\hline 1 & Tidak Sekolah & 0 & $0 \%$ \\
\hline 2 & SD & 0 & $0 \%$ \\
\hline 3 & SMP & 0 & $0 \%$ \\
\hline 4 & SMA/SMK & 10 & $40 \%$ \\
\hline 5 & Perguruan Tinggi & 15 & $60 \%$ \\
\hline & Total & 25 & 100 \\
\hline
\end{tabular}

Sedangkan untuk tingkat pendidikan para wisatawan saat kita lakukan penelitian untuk tingkat perguruan tinggi paling dominasi yaitu sebanyak $60 \%$ dan hanya $40 \%$ yang berpendidikan tingkat SMA/SMK. Sebagai wisatawan pendidikan yang berbasis alam wajar saja kalau banyak dikunjungi wisatawan yang ingin berwisata kembali ke alam. Wisatawan yang dominan dari kalangan terpelajar ingin selalu berwisata yang alami dan memanjakan selera hidupnya.

Tabel 4. Data Jenis Pekerjaan Wisatawan Bali Ndeso Kampung Flory

\begin{tabular}{|c|l|c|c|}
\hline No. & Keterangan & Frekuensi & Persentase \\
\hline 1 & TNI/POLRI & 0 & $0 \%$ \\
\hline 2 & PNS & 3 & $12 \%$ \\
\hline 3 & Karyawan Swasta & 11 & $44 \%$ \\
\hline 4 & Pedagang & 2 & $8 \%$ \\
\hline 5 & Petani & 0 & $0 \%$ \\
\hline 6 & Pensiunan & 0 & $0 \%$ \\
\hline 7 & Pelajar/Mahasiswa & 2 & $8 \%$ \\
\hline 8 & Pengusaha & 2 & $8 \%$ \\
\hline 9 & Lain-lain & 5 & $20 \%$ \\
\hline \multicolumn{2}{|c|}{ Total } & 25 & 100 \\
\hline
\end{tabular}

Untuk latar belakang profesi pengunjung wisata Bali Ndeso Kampung Flory adalah karyawan swasta yaitu sebanyak $44 \%$, PNS $12 \%$, Pengusaha dan Pelajar/Mahasiswa sebanyak $8 \%$. Sedangkan profesi lain-lain sebanyak $20 \%$.
Sebagai wisata alam desa dan kulineri yang berbasis pendidikan wajar saja wisatawan dengan segala latar belakang profesi banyak berkunjung ke obyek wisata ini dalam rangka belajar dan mencari suasana tenang dan nyaman.

Tabel 5. Data Pendapatan Wisatawan Bali Ndeso Kampung Flory

\begin{tabular}{|c|c|c|c|}
\hline No. & Keterangan & Frek & $\%$ \\
\hline 1 & 0 & 6 & $24 \%$ \\
\hline 2 & $<$ Rp.1.500.000 & 2 & $8 \%$ \\
\hline 3 & Rp. 1.600.000-Rp. 2.500.000 & 9 & $36 \%$ \\
\hline 4 & Rp. 2.600.000-Rp. 3.500.000 & 3 & $12 \%$ \\
\hline 5 & Rp. 3.600.000-Rp. 4.500.000 & 1 & $4 \%$ \\
\hline 6 & $>$ Rp. 4.500.000 & 3 & $12 \%$ \\
\hline & Total & 25 & 100 \\
\hline
\end{tabular}

Sedangkan untuk tingkat pendapatan bahwa wisatawan dengan pendapatan ratarata Rp. 1.600.000-Rp. 2.500.000 paling dominan yaitu $36 \%$ wisatawan. Kemudian pendapatan Rp. 2.600.000-Rp. 3.500 .000 sebanyak $12 \%$. Kemudian di atas Rp. 4.500 .000 sebanyak $12 \%$ wisatawan. Sedangkan yang belum berpenghasilan karena masih sekolah atau kuliah atau belum kerja sebanyak $8 \%$ responden saja.

\subsubsection{Data II Tentang Kualitas Pelayanan di Obyek Wisata Bali Ndeso Kampung Flory}

Data-data tentang kualitas layanan pada desa wisata kampung flory disajikan dalam tabel dibawah ini.

Tabel 6. Aspek Tangible Pelayanan di Obyek Wisata Bali Ndeso Kampung Flory

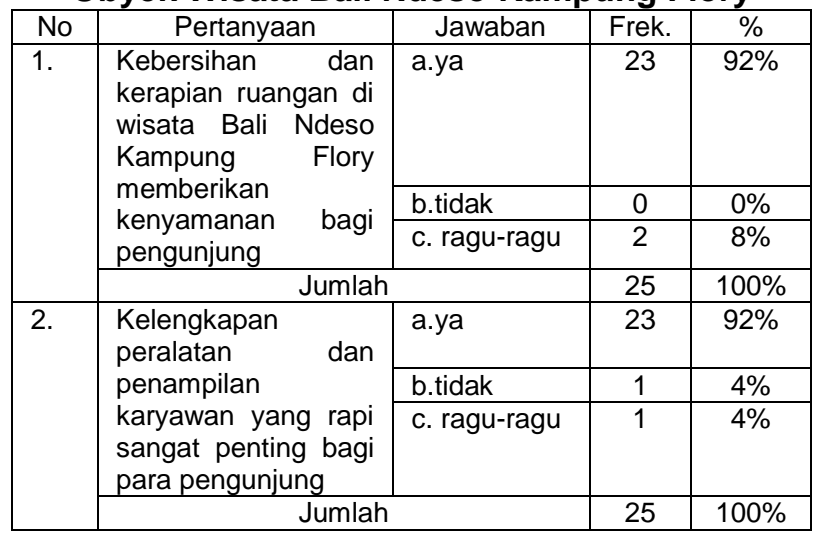

$$
\text { Kepuasaan pengunjung sangat }
$$

ditentukan oleh kualitas pelayanan yang diberikan oleh pengelola wisata Bali Ndeso Kampung Flory seperti Kebersihan dan kerapian ruangan yang memberikan rasa nyaman pengunjung. Hal ini dikatakan oleh 92\% responden yang mengatakan bahwa kualitas pelayanan yang ditentukan kebersihan dan kerapihan sudah baik dan kelengkapan peralatan dan penampilan karyawan Bali Ndeso yang rapi dihadapan pengunjung.

Tabel 7. Aspek Kehandalan Pelayanan di Obyek Wisata Bali Ndeso Kampung Flory \begin{tabular}{|l|l|l|l|l|}
\hline No & Pertanyaan & Jawaban & Frek. & $\%$ \\
\hline
\end{tabular} 


\begin{tabular}{|c|c|c|c|c|}
\hline \multirow[t]{4}{*}{3.} & \multirow{3}{*}{$\begin{array}{lr}\text { Wisata Bali } & \text { Ndeso } \\
\text { Kampung } & \text { Flory } \\
\text { selalu memberikan } \\
\text { pelayanan } & \text { tepat } \\
\text { waktu } & \text { kepada } \\
\text { pengunjung } & \end{array}$} & a.ya & 20 & $80 \%$ \\
\hline & & b.tidak & 2 & $8 \%$ \\
\hline & & $\begin{array}{l}\text { c. ragu- } \\
\text { ragu }\end{array}$ & 3 & $12 \%$ \\
\hline & \multicolumn{2}{|l|}{ Jumlah } & 25 & $100 \%$ \\
\hline \multirow[t]{4}{*}{4.} & \multirow{3}{*}{$\begin{array}{ll}\text { Wisata Bali } & \text { Ndeso } \\
\text { Kampung Flory akan } \\
\text { memberikan } \\
\text { informasi kepada } \\
\text { pengunjung tentang } \\
\text { perkiraan waktu } \\
\text { untuk } & \\
\text { menyelesaikan } \\
\text { pesanan } & \\
\text { pengunjung. } & \end{array}$} & a.ya & 22 & $88 \%$ \\
\hline & & b.tidak & 1 & $4 \%$ \\
\hline & & $\begin{array}{l}\text { c. ragu- } \\
\text { ragu }\end{array}$ & 2 & $8 \%$ \\
\hline & \multicolumn{2}{|l|}{ Jumlah } & 25 & $100 \%$ \\
\hline
\end{tabular}

Aspek kehandalan seperti memberikan pelayanan tepat waktu kepada pengunjung di Bali Ndeso Kampung diberikan penilaian yang baik yaitu sebanyak $80 \%$ dan hanya $8 \%$ yang menilai tidak tepat waktu. Selain itu pengunjung memberikan penilaian sebanyak $88 \%$ tentang memberikan informasi perkiraan waktu saat menyelesaikan pesanan pengunjung dan hanya $4 \%$ yang menjawan tidak tentang kepastian dalam menyelesaikan pesanan pengunjung.

Tabel 8. Aspek Daya Tanggap Pelayanan di Obyek Wisata Bali Ndeso Kampung Flory

\begin{tabular}{|c|c|c|c|c|}
\hline No & Pertanyaan & Jawaban & Frek. & $\%$ \\
\hline \multirow[t]{4}{*}{5.} & \multirow[t]{3}{*}{\begin{tabular}{lr} 
Wisata Bali & Ndeso \\
Kampung & Flory \\
selalu memberikan \\
pelayanan yang \\
\multicolumn{2}{l}{ cepat dan tepat }
\end{tabular}} & a.ya & 19 & $76 \%$ \\
\hline & & b.tidak & 3 & $12 \%$ \\
\hline & & c. ragu-ragu & 3 & $12 \%$ \\
\hline & \multicolumn{2}{|l|}{ Jumlah } & 25 & $100 \%$ \\
\hline \multirow[t]{4}{*}{6.} & \multirow{3}{*}{$\begin{array}{l}\text { Penyampaian } \\
\text { informasi dari } \\
\text { karyawan di Wisata } \\
\text { Bali Ndeso Kampung } \\
\text { Flory dilakukan } \\
\text { dengan jelas }\end{array}$} & a.ya & 22 & $88 \%$ \\
\hline & & b.tidak & 1 & $4 \%$ \\
\hline & & c. ragu-ragu & 2 & $8 \%$ \\
\hline & \multicolumn{2}{|l|}{ Jumlah } & 25 & $100 \%$ \\
\hline
\end{tabular}

Dalam aspek ketanggapan pelayanan sumberdaya manusia di wisata Bali Ndeso sudah berjalan dengan baik dimana $76 \%$ wisatawan memberikan penilaian yang bagus pada pelayanan yang cepat dan tepat dan $12 \%$ wisatawan masih ragu-ragu dan tidak dalam memberikan pelayanan yang cepat dan tepat. Saat libur akhir minggu dan libur panjang obyek wisata ini sangat ramai sehingga pelayanan kulineri harus pandaipandai mengatur waktu dalam pelayanan kepada wisatawan. Namun semua dihandle dengan baik, karena manajer Bali Ndeso juga ikut turun tangan jika obyek wisata ramai sekali terutama di usaha kulinerinnya.

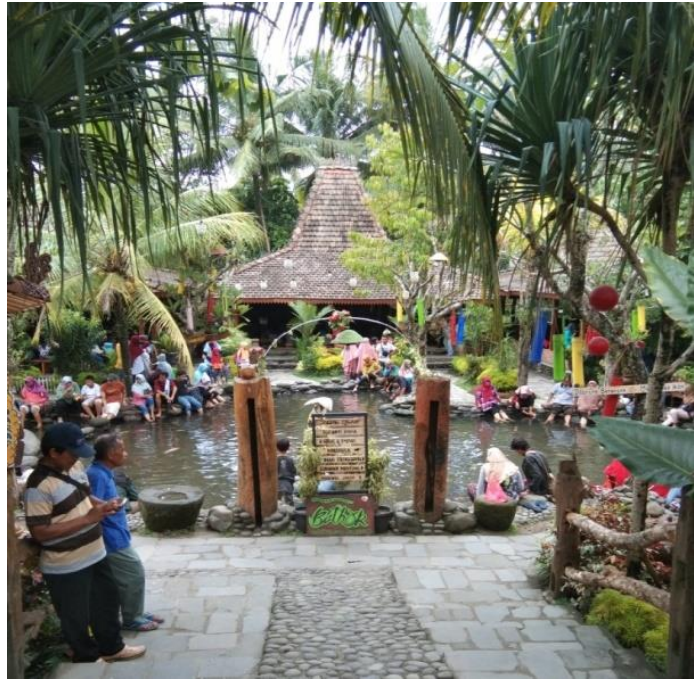

Gambar 3. Suasana Wisata Bali Ndeso Kampung Flory

Tabel 9. Aspek Keyakinan Pelayanan di Obyek Wisata Bali Ndeso Kampung Flory

\begin{tabular}{|c|c|c|c|c|}
\hline No & Pertanyaan & Jawaban & Frek. & $\%$ \\
\hline \multirow[t]{4}{*}{7.} & \multirow{3}{*}{$\begin{array}{lr}\text { Kesopan } & \text { santunan } \\
\text { karyawan } & \text { Wisata } \\
\text { Bali } & \text { Ndeso } \\
\text { Kampung } & \text { Flory } \\
\text { dalam } & \text { memberi } \\
\text { pelayanan } & \text { dan } \\
\text { keterampilan } & \text { dalam } \\
\text { memberikan } & \\
\text { informasi } & \text { sudah } \\
\text { cukup baik. } & \end{array}$} & a.ya & 22 & $88 \%$ \\
\hline & & b.tidak & 0 & $0 \%$ \\
\hline & & $\begin{array}{l}\text { c. ragu- } \\
\text { ragu }\end{array}$ & 3 & $12 \%$ \\
\hline & \multicolumn{2}{|l|}{ Jumlah } & 25 & $100 \%$ \\
\hline \multirow[t]{4}{*}{8.} & \multirow{3}{*}{$\begin{array}{l}\text { Kemampuan dalam } \\
\text { memberikan } \\
\text { keamanan dan } \\
\text { kemampuan dalam } \\
\text { menanamkan } \\
\text { kepercayaan sudah } \\
\text { baik. }\end{array}$} & a.ya & 23 & $92 \%$ \\
\hline & & b.tidak & 0 & $0 \%$ \\
\hline & & $\begin{array}{l}\text { c. ragu- } \\
\text { ragu }\end{array}$ & 2 & $8 \%$ \\
\hline & \multicolumn{2}{|l|}{ Jumlah } & 25 & $100 \%$ \\
\hline
\end{tabular}
wisatawan memberikan penilaian yang baik $88 \%$ yaitu kemampuan memberikan informasi kepada wisatawan dan $92 \%$ wisatawan juga memberikan penilaian yang baik dimana karyawan memberikan rasa aman dan kepercayaan pada wisatawan saat berkunjung di obyek wisata ini. Manajemen Bali Ndeso selalu menanamkan pelatihan kepada sumberdaya manusiannya untuk melayani dengan baik terutama aspek rasa aman dan kepercayaan pada wisatawan saat berkunjung di obyek wisata ini. Aspek control selalu ditekankan pada semua sarana-prasarana yang ada di obyek wisata ini, sehingga wisatawan merasa nyaman dan aman menikmati wisata disini.

Tabel 10. Aspek Empathy Pelayanan di Obyek Wisata Bali Ndeso Kampung Flory \begin{tabular}{|c|c|c|c|c|}
\hline No & Pertanyaan & Jawaban & Frek. & $\%$ \\
\hline
\end{tabular} 


\begin{tabular}{|c|c|c|c|c|c|}
\hline \multirow[t]{4}{*}{9.} & \multirow{3}{*}{\multicolumn{2}{|c|}{$\begin{array}{lr}\text { Karyawan } & \text { Wisata } \\
\text { Bali } & \text { Ndeso } \\
\text { Kampung } & \text { Flory } \\
\text { mudah } & \text { menjalin } \\
\text { hubungan } & \text { dan } \\
\text { berkomunikasi } & \\
\text { dengan } & \text { baik } \\
\text { dengan } & \text { para } \\
\text { penguniung } & \end{array}$}} & a.ya & 23 & $92 \%$ \\
\hline & & & b.tidak & 0 & $0 \%$ \\
\hline & & & c. ragu-ragu & 2 & $8 \%$ \\
\hline & \multicolumn{3}{|c|}{ Jumlah } & 25 & $100 \%$ \\
\hline \multirow[t]{4}{*}{10.} & \multirow{3}{*}{\multicolumn{2}{|c|}{$\begin{array}{lr}\text { Karyawan } & \text { selalu } \\
\text { memberikan } & \\
\text { perhatian } & \text { secara } \\
\text { pribadi } & \text { dan } \\
\text { memahami } & \\
\text { kebutuhan } & \text { para } \\
\text { pengunjug } & \\
\end{array}$}} & a.ya & 19 & $76 \%$ \\
\hline & & & b.tidak & 1 & $4 \%$ \\
\hline & & & c. ragu-ragu & 5 & $20 \%$ \\
\hline & \multicolumn{3}{|c|}{ Jumlah } & 25 & $100 \%$ \\
\hline
\end{tabular}

Untuk aspek empathy pada wisatawan bahwa sumberdaya manusia di Bali Ndeso sudah menjalin baik dalam hubungan dan komunikasi dalam pelayanan dimana $92 \%$ mereka menilai sudah baik dan wisatawan $76 \%$ memberikan penilaian yang baik kepada karyawan dalam memberikan perhatian secara pribadi terhadap kebutuhannya. Namun ada $4 \%$ dan $20 \%$ wisatawan yang memberikan penilain belum dan ragu-ragu dalam pemenuhan secara pribadi kebutuhan memberikan pelayanan yang dianggap baik.

Dalam situasi ramai kadang-kadang wisatawan masih ada yang belum terlayani dengan baik dalam hal pelayanan kulineri namun kendala tersebut dapat diatasi dengan baik ketika manajemen ikut membantu kerja sumberdaya yang ada.

\subsubsection{Data II Tentang Fasilitas Pelayanan di Obyek Wisata Bali Ndeso Kampung Flory \\ Data-data tentang fasilitas layanan yang} pada desa wisata kampung flory disajikan dalam tabel dibawah ini.

Tabel 11. Aspek Tentang Pertimbangan dan perencanaan lahan di Obyek Wisata Bali Ndeso Kampung Flory.

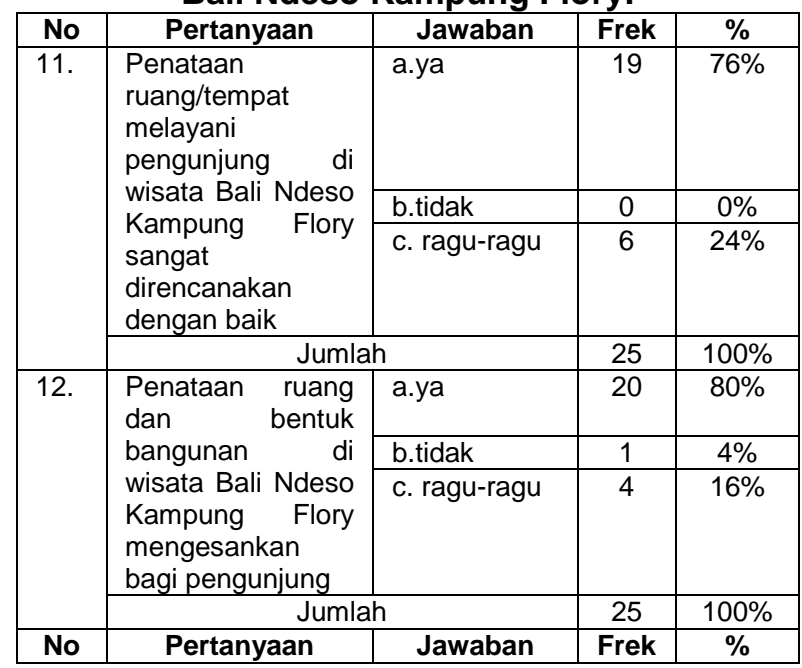

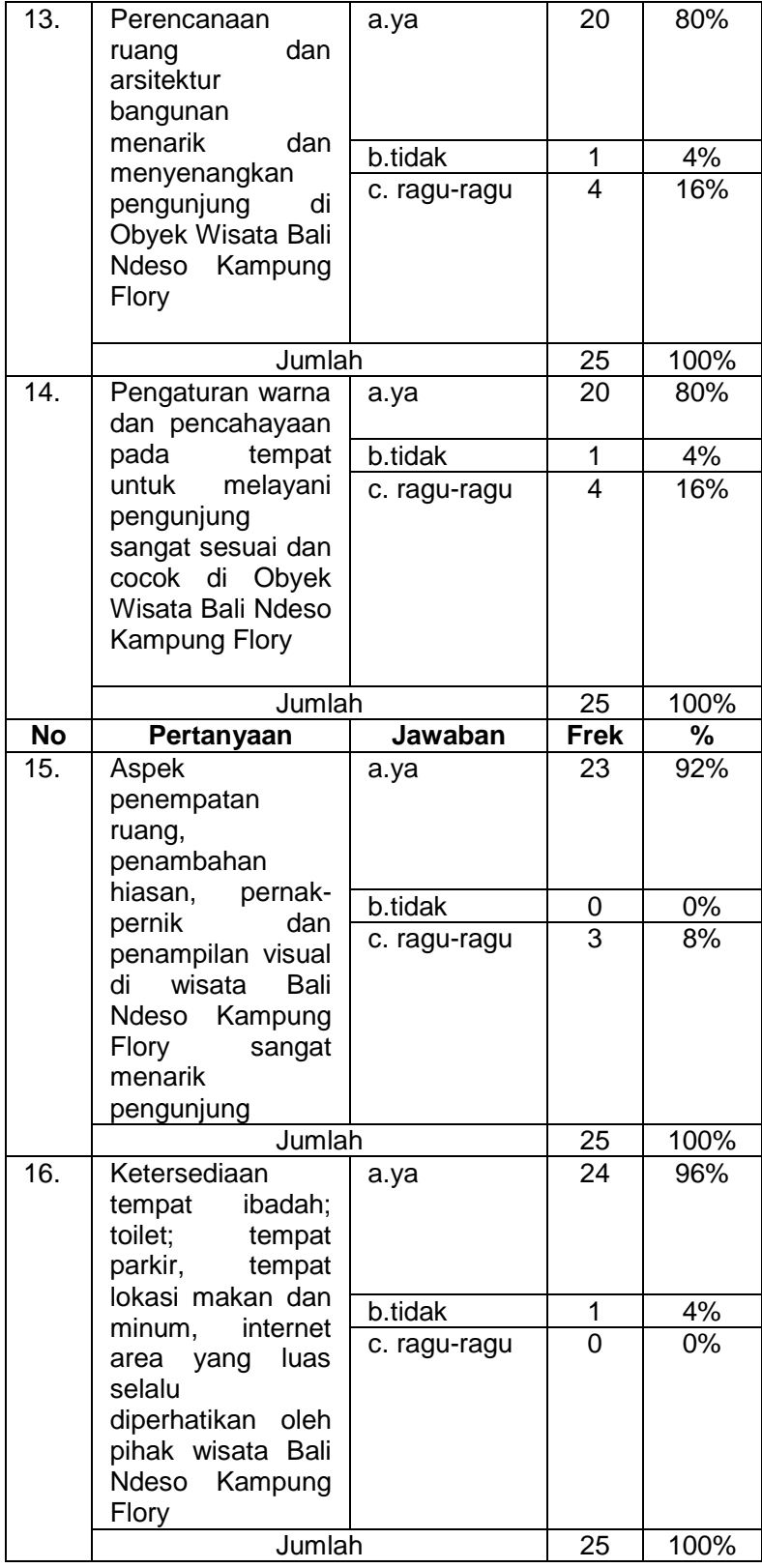

Aspek tentang pertimbangan dan perencanaan lahan di obyek wisata Bali Ndeso untuk penataan tata ruang dinilai baik dan menarik hal diutarakan oleh $76 \%$ wisatawan. Aspek inilah yang menjadikan obyek wisata ini banyak dikunjungi wisatawan karena tempatnya yang alami ditunjang saranaprasarana yang lengkap. Penataan ruang dan bentuk bangunan di wisata Bali Ndeso Kampung Flory mengesankan bagi pengunjung hal ini di menjadikan wisata menilai sangat berkesan $80 \%$ dan $16 \%$ yang masih menilai ragu-ragu. Pengaturan warna dan pencahayaan pada tempat untuk melayani pengunjung sangat sesuai dan cocok di Obyek Wisata Bali Ndeso Kampung Flory hal ini yang dikatakan wisatawan $80 \%$. Aspek penempatan ruang, penambahan hiasan, pernak-pernik dan penampilan visual di wisata Bali Ndeso 
Kampung Flory sangat menarik pengunjung hal ini dikatakan 92\% wisatawan. Selain wisatawan juga mengatakan setuju pengelola menyediakan tempat ibadah; toilet; tempat parkir, tempat lokasi makan dan minum, internet area yang luas dan hanya 4\% yang masih menyatakan ragu-ragu.

Manajemen Bali Ndeso Kampung Flory Sleman sangat memahami tentang penataan wisata ini, dari awal sudah dibuat seperti suasana kembali ke desa dan alami sehingga nantinya pengunjung menjadi betah dan menceritakan kepada saudara-saudara dan teman-temannya untuk berkunjung ke obyek wisata ini. Meski didekat ibu kota Kabupaten Sleman, namun lokasinya sangat alami dan penuh pedesaaan sehingga pengunjung ramai sekali menikmati suasana alamnya.Tempat outboundnya juga membuat pengunjung terutama anak-anak senang dengan suasana yang alami sehingga belajar kembali ke desa sangat cocok ditempat ini.

\subsubsection{Data III Tentang Persepsi Harga Dan Lokasi Pelayanan Di Obyek Wisata Bali Ndeso Kampung Flory}

Data-data tentang persepsi harga dan lokasi layanan desa wisata kampung flory disajikan dalam tabel dibawah ini

Tabel 12. Aspek Persepsi Harga Di Obyek Wisata Bali Ndeso Kampung Flory

\begin{tabular}{|c|c|c|c|c|}
\hline No & Pertanyaan & Jawaban & Frek & $\%$ \\
\hline \multirow[t]{4}{*}{17.} & \multirow{3}{*}{$\begin{array}{lr}\text { Kesesuaian } & \text { harga } \\
\text { produk } & \text { dengan } \\
\text { kualitas produk di } & \\
\text { wisata Bali } & \text { Ndeso } \\
\text { Kampung } & \text { Flory } \\
\text { sudah } & \text { cukup } \\
\text { sesuai. } & \end{array}$} & a.ya & 20 & $80 \%$ \\
\hline & & b.tidak & 2 & $8 \%$ \\
\hline & & c. ragu-ragu & 3 & $12 \%$ \\
\hline & \multicolumn{2}{|c|}{ Jumlah } & 25 & $100 \%$ \\
\hline \multirow[t]{4}{*}{18.} & \multirow{3}{*}{\begin{tabular}{l}
\multicolumn{3}{l}{ Perbandingan } \\
harga dengan \\
harga produk \\
wisata Bali Ndeso \\
Kampung Flory \\
dengan yang lain \\
cukup bersaing
\end{tabular}} & a.ya & 21 & $84 \%$ \\
\hline & & b.tidak & 1 & $4 \%$ \\
\hline & & c. ragu-ragu & 3 & $12 \%$ \\
\hline & \multicolumn{2}{|l|}{ Jumlah } & 25 & $100 \%$ \\
\hline No & Pertanyaan & Jawaban & Frek & $\%$ \\
\hline \multirow[t]{4}{*}{19.} & \multirow{3}{*}{\begin{tabular}{l} 
Kesesuaian harga \\
produk wisata Bali \\
Ndeso Kampung \\
Flory dengan \\
manfaat yang \\
didapat pengunjung \\
\multicolumn{2}{l}{ sudah sesuai } \\
\end{tabular}} & a.ya & 24 & $96 \%$ \\
\hline & & b.tidak & 0 & $0 \%$ \\
\hline & & c. ragu-ragu & 1 & $4 \%$ \\
\hline & \multicolumn{2}{|c|}{ Jumlah } & 25 & $100 \%$ \\
\hline
\end{tabular}

Untuk persepsi harga di wisata Bali Ndeso Kampung Flory sudah cukup sesuai antara kualitas produk dengan harga produk hal dikatakan $80 \%$ pengunjung dan hanya $8 \%$ saja yang mengatakan tidak sesuai. Sehingga $96 \%$ pengunjung juga mengatakan bahwa harga produk wisata sesuai dengan manfaat yang didapat pengunjung selama berkunjung ditempat tersebut.
Tabel 13. Aspek Lokasi Di Obyek Wisata Bali Ndeso Kampung Flory

\begin{tabular}{|c|c|c|c|c|}
\hline No & Pertanyaan & Jawaban & Frek & $\%$ \\
\hline \multirow[t]{4}{*}{20.} & \multirow[t]{3}{*}{$\begin{array}{lr}\text { Lokasi } & \text { wisata Bali } \\
\text { Ndeso } & \text { Kampung } \\
\text { Flory } & \text { mudah } \\
\text { dijangkau } & \text { sarana } \\
\text { transportasi umum. }\end{array}$} & a.ya & 21 & $84 \%$ \\
\hline & & b.tidak & 3 & $12 \%$ \\
\hline & & c. ragu-ragu & 1 & $4 \%$ \\
\hline & \multicolumn{2}{|c|}{ Jumlah } & 25 & $100 \%$ \\
\hline \multirow[t]{4}{*}{21.} & \multirow{3}{*}{$\begin{array}{l}\text { Lokasi wisata Bali } \\
\text { Ndeso Kampung } \\
\text { Flory dapat dilihat } \\
\text { dengan jelas dari } \\
\text { arah jalur } \\
\text { transportasi } \\
\text { manapun. }\end{array}$} & a.ya & 19 & $76 \%$ \\
\hline & & b.tidak & 4 & $16 \%$ \\
\hline & & c. ragu-ragu & 2 & $8 \%$ \\
\hline & \multicolumn{2}{|l|}{ Jumlah } & 25 & $100 \%$ \\
\hline No & Pertanyaan & Jawaban & Frek & $\%$ \\
\hline \multirow[t]{4}{*}{22.} & \multirow{3}{*}{$\begin{array}{lr}\text { Jalur Yogyakarta- } \\
\text { Borobudur- } \\
\text { Semarangi di depan } \\
\text { wisata Bali } & \text { Ndeso } \\
\text { Kampung } & \text { Flory } \\
\text { merupakan jalur } & \text { jama dan wisata } \\
\text { utama } & \text { sehingga sangat } \\
\text { memudahkan } \\
\text { pengunjung untuk } \\
\text { datang. }\end{array}$} & a.ya & 21 & $84 \%$ \\
\hline & & b.tidak & 2 & $8 \%$ \\
\hline & & c. ragu-ragu & 2 & $8 \%$ \\
\hline & \multicolumn{2}{|l|}{ Jumlah } & 25 & $100 \%$ \\
\hline \multirow[t]{4}{*}{23} & \multirow{3}{*}{$\begin{array}{lr}\text { Tempat } & \text { parkir } \\
\text { wisata Bali } & \text { Ndeso } \\
\text { Kampung } & \text { Flory } \\
\text { cukup luas,nyaman } \\
\text { dan aman }\end{array}$} & a.ya & 22 & $88 \%$ \\
\hline & & b.tidak & 1 & $4 \%$ \\
\hline & & c. ragu-ragu & 2 & $8 \%$ \\
\hline & \multicolumn{2}{|l|}{ Jumlah } & 25 & $100 \%$ \\
\hline No & Pertanyaan & Jawaban & Frek & $\%$ \\
\hline \multirow[t]{4}{*}{24} & \multirow{3}{*}{$\begin{array}{l}\text { Tempat wisata Bali } \\
\text { Ndeso Kampung } \\
\text { Flory memiliki } \\
\text { tempat yang cukup } \\
\text { luas untuk } \\
\text { perluasan usaha di } \\
\text { kemudian hari }\end{array}$} & a.ya & 22 & $88 \%$ \\
\hline & & b.tidak & 2 & $8 \%$ \\
\hline & & c. ragu-ragu & 1 & $4 \%$ \\
\hline & \multicolumn{2}{|c|}{ Jumlah } & 25 & $100 \%$ \\
\hline No & Pertanyaan & Jawaban & Frek & $\%$ \\
\hline \multirow[t]{4}{*}{25} & \multirow{3}{*}{$\begin{array}{lr}\text { Lingkungan } & \text { sekitar } \\
\text { wisata Bali } & \text { Ndeso } \\
\text { Kampung } & \text { Flory } \\
\text { mendukung } & \text { bagi } \\
\text { seluruh } & \text { produk } \\
\text { yang ditawarkan }\end{array}$} & a.ya & 23 & $92 \%$ \\
\hline & & b.tidak & 2 & $8 \%$ \\
\hline & & c. ragu-ragu & 0 & $0 \%$ \\
\hline & \multicolumn{2}{|c|}{ Jumlah } & 25 & $100 \%$ \\
\hline No & Pertanyaan & Jawaban & Frek & $\%$ \\
\hline \multirow[t]{4}{*}{26} & \multirow{3}{*}{$\begin{array}{lr}\text { Lokasi yang ada } \\
\text { bagi pesaing wisata } \\
\text { Bali } & \text { Ndeso } \\
\text { Kampung } & \text { Flory } \\
\text { masih } & \text { sedikit } \\
\text { sehingga } & \text { masih } \\
\text { memungkinkan } & \\
\text { untuk bersaing } \\
\text { usaha }\end{array}$} & a.ya & 23 & $92 \%$ \\
\hline & & b.tidak & 1 & $4 \%$ \\
\hline & & c. ragu-ragu & 1 & $4 \%$ \\
\hline & Jumlah & & 25 & $100 \%$ \\
\hline
\end{tabular}

Aspek lokasi di obyek wisata Bali Ndeso Kampung Flory sangat menentukan untuk kepuasaan pengunjung di obyek ini, dengan lokasi yang strategis karena tidak jauh dari jalan raya Yogya-Semarang sehingga 
pengunjung mudah menemukan obyek wisata ini. Hal dikatakan $84 \%$ pengunjung, Petunjuk arah yang jelas memudahkan pengunjung mengakses obyek wisata ini hal ini dikatakan oleh $76 \%$ pengunjung yang telah berkunjung ditempat tersebut. Lingkungan sekitar wisata Bali Ndeso Kampung Flory mendukung bagi seluruh produk yang ditawarkan hal ini dikatakan oleh $92 \%$ dan hanya $8 \%$ saja yang menyatakan tidak mendukung. Di obyek wisata karena suasana alam yang dijual tentunya obyek wisata menjadi favorit banyak dikunjungi dengan wisata pendidikan dan kulinerinya menjadi lengkap sebagai pendukung wisata alam pedesaan ini. Air yang melimpah dan udara yang masih sejuk menyebabkan wisatawan betah berlama-lama di obyek wisata ini.

Lokasi wisata Bali Ndeso Kampung Flory dapat dilihat dengan jelas dari arah jalur transportasi manapun hal ini menurut pendapat $76 \%$ pengunjung dan hanya $16 \%$ yang mengatakan tidak hal ini dikarenakan wisatawan masih menggunakan petunjuk manual yaitu papan petunjuk lokasi obyek wisata ini, sekarang wisatawan sudah bisa mengakses di alat komunikasinya seperti smartphone, tablet atau laptop dan lain-lain bahwa obyek wisata dapat dilihat di google map sehingga mudah mencari obyek wisata tanpa tersesat.

Tempat wisata Bali Ndeso Kampung Flory memiliki tempat yang cukup luas untuk perluasan usaha sehingga obyek wisata ini dapat dikembangkan lebih luas lagi dengan luas tanah yang masih mendukung bisa menjadi kenyataan nantinya obyek wisata dapat dikembangkan lebih besar. Seperti pendapat $88 \%$ responden yang menyatakan bahwa Bali Ndeso dapat diperluas lebih besar lagi suatu saat dengan melihat luas tanah yang masih mendukung. Hanya $8 \%$ yang menyatakan tidak dan $4 \%$ menjawab raguragu. Lingkungan sekitar wisata Bali Ndeso Kampung Flory mendukung bagi seluruh produk yang ditawarkan hal dikatakan 92\% wisatawan, manajemen atau pengelola dari awal pendirian obyek wisata selalu metitikberatkan pemberdayaan masyarakat. Semua masyarakat di lingkungan ini selalu dilibatkan mendukung pengembangan obyek wisata ini.

Lokasi yang ada bagi pesaing wisata Bali Ndeso Kampung Flory masih sedikit sehingga masih memungkinkan untuk bersaing usaha hal ini dikatakan oleh 92\% wisatawan. Obyek wisata seperti Bali Ndeso Kampung Flory masih sedikit di wilayah Kabupaten Sleman sehingga kompetitornya masih sedikit. Obyek wisata yang menyelaraskan wisata alam yang didalamnya banyak unsur pendidikan tentunya menjadi ciri khas pengembangan obyek wisata ini untuk menjadi besar lagi. Ciri khas yang lain bahwa Bali Ndeso dengan alam pedesaan meski di lingkungan modern namun tetap memikat pengunjung untuk berwisata karena suasana alam yang masih segar dan alami. Konsep yang dirancang oleh pengelola menjadikan obyek wisata ini disulap dari lahan yang tidak produktif menjadi produktif sehingga menjadikan masyarakatnya yang terdampak ikut merasakan manfaatnya yaitu ekonomi menjadi meningkat.

\subsubsection{Data IV Kepuasaan Pengunjung Di Obyek Wisata Bali Ndeso Kampung Flory}

Data-data tentang kepuasan pengunjung desa wisata kampung flory disajikan dalam tabel dibawah ini.

Tabel 15. Aspek Kepuasaan Pelayanan Di

Obyek Wisata Bali Ndeso Kampung Flory

\begin{tabular}{|c|c|c|c|c|}
\hline No & Pertanyaan & Jawaban & Frek & $\%$ \\
\hline \multirow[t]{6}{*}{27.} & \multirow{5}{*}{$\begin{array}{l}\text { Obyek wisata Bali } \\
\text { Ndeso Kampung } \\
\text { Flory sudah } \\
\text { menyediakan } \\
\text { layanan yang baik } \\
\text { terhadap } \\
\text { pengunjung }\end{array}$} & \multirow[t]{3}{*}{ a.ya } & \multirow[t]{3}{*}{22} & \multirow[t]{3}{*}{$88 \%$} \\
\hline & & & & \\
\hline & & & & \\
\hline & & b.tidak & 0 & $0 \%$ \\
\hline & & c. ragu-ragu & 3 & $12 \%$ \\
\hline & \multicolumn{2}{|c|}{ Jumlah } & 25 & $100 \%$ \\
\hline \multirow[t]{5}{*}{28.} & \multirow{4}{*}{$\begin{array}{lr}\text { Karyawan } & \text { wisata } \\
\text { Bali } & \text { Ndeso } \\
\text { Kampung } & \text { Flory } \\
\text { cepat } & \text { dalam } \\
\text { menyelesaikan } \\
\text { pekerjaan }\end{array}$} & a.ya & 19 & $76 \%$ \\
\hline & & b.tidak & 0 & $0 \%$ \\
\hline & & c. ragu-ragu & 6 & $24 \%$ \\
\hline & & & & \\
\hline & \multicolumn{2}{|c|}{ Jumlah } & 25 & $100 \%$ \\
\hline No & Pertanyaan & Jawaban & Frek & $\%$ \\
\hline \multirow[t]{5}{*}{29.} & \multirow{4}{*}{$\begin{array}{lr}\text { Karyawan } & \text { wisata } \\
\text { Bali } & \text { Ndeso } \\
\text { Kampung } \quad \text { Flory } \\
\text { tanggap terhadap } \\
\text { keluhan } \\
\text { pengunjung }\end{array}$} & a.ya & 18 & $72 \%$ \\
\hline & & & & \\
\hline & & $\mathrm{h}$ tidak & 0 & $0 \%$ \\
\hline & & c. ragu-ragu & 7 & $18 \%$ \\
\hline & \multicolumn{2}{|c|}{ Jumlah } & 25 & $100 \%$ \\
\hline No & Pertanyaan & Jawaban & Frek & $\%$ \\
\hline \multirow[t]{6}{*}{30.} & \multirow{5}{*}{$\begin{array}{lr}\text { Karyawan wisata } \\
\text { Bali Ndeso } \\
\text { Kampung Flory } \\
\text { memberikan } \\
\text { perhatian individu } \\
\text { dengan baik } \\
\text { kepada keluhan } \\
\text { pengunjung }\end{array}$} & a.ya & 18 & $72 \%$ \\
\hline & & & & \\
\hline & & & & \\
\hline & & b.tidak & 1 & $4 \%$ \\
\hline & & c. ragu-ragu & 6 & $24 \%$ \\
\hline & \multicolumn{2}{|c|}{ Jumlah } & 25 & $100 \%$ \\
\hline
\end{tabular}

Penelitian ini lebih menekankan pada kepuasaan pengunjung wisata di obyek wisata Bali Ndeso Kampung Flory tentunya penilaian wisatawan mengenai kepuasaan dari dampak pengembangan obyek wisata ini terutama dalam menyediakan layanan. Dalam penyediaan pelayanan yang baik terhadap pengunjung bahwa $88 \%$ pengunjung 
menyatakan sudah baik dan hanya $12 \%$ yang menyatakan masih mengatakan ragu-ragu. Karyawan wisata Bali Ndeso Kampung Flory cepat dalam menyelesaikan pekerjaan hal ini dikatakan oleh $19 \%$ pengunjung dan hanya $24 \%$ menjawab ragu-ragu. Karyawan wisata Bali Ndeso Kampung Flory tanggap terhadap keluhan pengunjung hal dikatakan oleh $72 \%$ wisatawan dan hanya $18 \%$ yang menjawab ragu-ragu. Karyawan wisata Bali Ndeso Kampung Flory memberikan perhatian individu dengan baik kepada keluhan pengunjung hal dikatakan oleh $72 \%$ pengunjung dan hanya $4 \%$ menjawab tidak serta $24 \%$ menjawab ragu-ragu.

Komitmen pengelola atau manajemen Bali Ndeso Kampung Flory dalam memberikan pelayanan yang baik untuk mewujudkan kepuasaan pengunjung, semua karyawan dan masyarakat di obyek wisata ini diberi pemahaman bahwa obyek wisata akan selalu tetap dikunjungi jika semua berperan dalam memberikan pelayanan yang prima. Tidak perlu pemasaran yang tinggi dengan pelayanan yang memberikan kepuasaan pengunjung akan selalu datang ke obtek wisata ini. Referensi pengunjung kepada saudara, teman dan tetangga menjadikan pengunjung percaya bahwa obyek wisata selalu memberikan perhatian kepada kebutuhan wisatawan yaitu wisata yang aman dan nyaman serta berkesan setelah berkunjung.

\subsection{Kesimpulan}

Pengelolaan dan Pengembangan obyek wisata Bali Ndeso Kampung Flory sudah berjalan baik dalam aspek sumber daya manusia dan kinerja pelayanan kepada pengunjung atau wisatawan. Aspek-aspek yang ada dalam pengelolaan obyek wisata menjadi indikator capaian terhadap kepuasaan wisatawan. Hal ini dapat dianalisis dalam penelitian tentang studi kepuasaan pengunjung di obyek wisata Bali Ndeso yang dapat disimpulkan sebagai berikut :

1. Menurut mayoritas pengunjung yang menjadi sampel dalam penelitian mengatakan bahwa kualitas pelayanan dari aspek kebersihan dan kerapihan sudah baik serta ditunjang dengan peralatan dan penampilan karyawan Bali Ndeso yang rapi dihadapan pengunjung.

2. Dalam aspek kehandalan dalam memberikan pelayanan kepada pengunjung di Bali Ndeso Kampung sudah tepat waktu .
3. Sumberdaya manusia di Bali Ndeso sudah menjalin baik dalam hubungan dan komunikasi dalam pelayanan kepada wisatawan sehingga apa yang diinginkan wisatawan terpenuhi.

4. Untuk persepsi harga di wisata Bali Ndeso Kampung Flory sudah cukup sesuai antara kualitas produk dengan harga produk yang ditawarkan.

5. Aspek lokasi di obyek wisata Bali Ndeso Kampung Flory sangat menentukan untuk kepuasaan pengunjung di obyek ini karena lokasi yang strategis dan mudah dijangkau dengan petunjuk serta peta lokasi yang mudah dicari.

6. Dalam penyediaan pelayanan terhadap pengunjung bahwa mayoritas pengunjung menyatakan sudah baik.

7. Karyawan wisata Bali Ndeso Kampung Flory tanggap terhadap keluhan pengunjung saat pengunjung menjumpai ada masalah dan selalu memperhatikan secara individu dalam keluhahannya sehingga kepuasaan pengunjung dapat tercapai secara optimal.

\section{Daftar Pustaka}

[1] Anonim, Undang-Undang Republik Indonesia Nomor 9 Tahun 1990 Tentang Kepariwisataan. Jakarta

[2] Anonim, Undang-Undang Republik Indonesia Nomor 8 Tahun 1999 Tentang Perlindungan Konsumen. Jakarta

[3] Anonim, Undang-Undang Republik Indonesia Nomor 10 Tahun 2009 Tentang Kepariwisataan. Jakarta

[4] Gamal, Suwantoro. 2002. Dasar-Dasar Pariwisata. Yogyakarta: Andi Offset.

[5] Ismayanti, 2010. Pengantar Pariwisata. Jakarta : PT Grasindo.

[6] Kuntowijoyo, 2006. Budaya dan Masyarakat: Edisi Paripurna. Yogyakarta :Tiara Wacana

[7] Kotler, Philip, 2002, Manajemen Pemasaran, Jilid I, Edisi Indonesia, Edisi Milenium,Edisi Kesepuluh, Jakarta : PT. Prenhallindo

[8] Majid, Suharto Abdul, 2009, Customer Service Dalam Bisnis Jasa Transportasi, Jakarta : PT Raja Grafindo Persada.

[9] Sihite, Richard, 2000, Tourism Industry (Kepariwisataan), Surabaya: Penerbit SIC

[10] Sugiyono, 2008, Metode Penelitian Kuantitatif dan $R \& D$. Bandung : Alfabeta

[11]Yoeti, Oka, Pemasaran Pariwisata Terpadu, Penerbit Angkasa, Bandung 1996 